\title{
Highly Selective, Amine-Derived Cannabinoid Receptor 2 Probes
}

Matthias V. Westphal, ${ }^{[a]}$ Roman C. Sarott, ${ }^{[a]}$ Elisabeth A. Zirwes, ${ }^{[b]}$ Anja Osterwald, ${ }^{[b]}$ Wolfgang Guba, ${ }^{[b]}$ Christoph Ullmer, ${ }^{[b]}$ Uwe Grether, ${ }^{[b]}$ Erick M. Carreira*[a]

\begin{abstract}
The endocannabinoid (eCB) system is implied in various human diseases ranging from central nervous system to autoimmune disorders. Cannabinoid receptor $2\left(\mathrm{CB}_{2} \mathrm{R}\right)$ is an integral component of the eCB system. Yet, the downstream effects elicited by this $\mathrm{G}$ protein-coupled receptor upon binding of endogenous or synthetic ligands are insufficiently understood-likely due to the limited arsenal of reliable biological and chemical tools. Herein, we report the design and synthesis of $\mathrm{CB}_{2} \mathrm{R}$-selective cannabinoids along with their in vitro pharmacological characterization (binding and functional studies). They combine structural features of HU-308 and AM841 to give chimeric ligands that emerge as potent $C_{3} R$ agonists with high selectivity over the closely related cannabinoid receptor $1\left(C_{1} R\right)$. The synthesis work includes convenient preparation of substituted resorcinols often found in cannabinoids. The utility of the synthetic cannabinoids in this study is showcased by preparation of the most selective high-affinity fluorescent probe for $\mathrm{CB}_{2} \mathrm{R}$ to date.
\end{abstract}

\section{Introduction}

The recognition of (-)- $\Delta^{9}$-trans-tetrahydrocannabinol as the main active ingredient in Cannabis sativa preparations ${ }^{1}$ marks the beginning of a series of important discoveries that unraveled a lipid signaling system referred to as endocannabinoid (eCB) system. ${ }^{2}$ The eCB system is found in all vertebrates and comprises (at least) two $G$ proteincoupled receptors known as cannabinoid receptors 1 and $2\left(C_{1} R\right.$ and $\left.C_{2} R\right)$, endogenous lipidic ligands including $\mathrm{N}$-arachidonoylethanolamine (also known as anandamide) and 2-arachidonoyl glycerol, as well as enzymes responsible for ligand metabolism. ${ }^{3}$ The eCB system is implied in numerous processes such as memory, nociception and immune response, ${ }^{4}$ and virtually all components of the eCB system have been considered as promising targets for the treatment of psychiatric disorders, autoimmune diseases, cancer and various other conditions. ${ }^{5,6}$ Yet, the underlying mechanism of $\mathrm{CB}_{1} \mathrm{R}$ - and $\mathrm{CB}_{2} \mathrm{R}$-mediated effects upon receptor modulation is insufficiently understood, especially in a tissue- and disease-dependent context. $\mathrm{CB}_{2} \mathrm{R}$ in particular, commonly referred to as peripheral cannabinoid receptor, has been shown to be upregulated in brain microglia during neuroinflammation, ${ }^{7}$ while its expression in cells of the healthy central nervous system is still under debate. ${ }^{8}$ Investigations of $\mathrm{CB}_{2} \mathrm{R}$ biology are made difficult due to low expression levels (if present at all), the inducible nature of $\mathrm{CB}_{2} \mathrm{R}$ and the lack of reliable and selective protein detection tools, such as antibodies. ${ }^{9}$ In general, functional derivatives of small molecules ${ }^{10}$ are an alternative that may specifically engage targets and enable applications such as fluorescence-activated cell sorting and confocal

[a] Dr. M. V. Westphal, R. C. Sarott, Prof. E. M. Carreira Laboratorium für Organische Chemie

Eidgenössische Technische Hochschule Zürich,

Vladimir-Prelog-Weg 3, 8093 Zürich, Switzerland E-Mail: erickm.carreira@org.chem.ethz.ch

[b] E. A. Zirwes, A. Osterwald, Dr. W. Guba, Dr. C. Ullmer, Dr. U. Grether Roche Innovation Center Basel, F. Hoffmann-La Roche Ltd. Grenzacherstrasse 124, Basel 4070, Switzerland microscopy (fluorescent probes), activity/affinity-based protein profiling (electrophilic or photoactivatable ligands) ${ }^{11,12}$ and targeted protein degradation (PROTACs), ${ }^{13}$ to name just a few.

The search for an irreversible $C_{2} R$-selective ligand. In combination with protein engineering, small molecule ligands for $\mathrm{CB}_{2} \mathrm{R}$ could help identifying a structural basis for $\mathrm{CB}_{2} \mathrm{R}$ 's pronounced biased signaling. ${ }^{14,15}$ Chemical probes that bind irreversibly would be particularly useful to investigate biological effects following continued receptor modulation, as stabilizing agents for crystallographic studies, and for antibody generation. However, despite decades of cannabinoid receptor research, no selective, irreversible binder for $\mathrm{CB}_{2} \mathrm{R}$ has been reported.

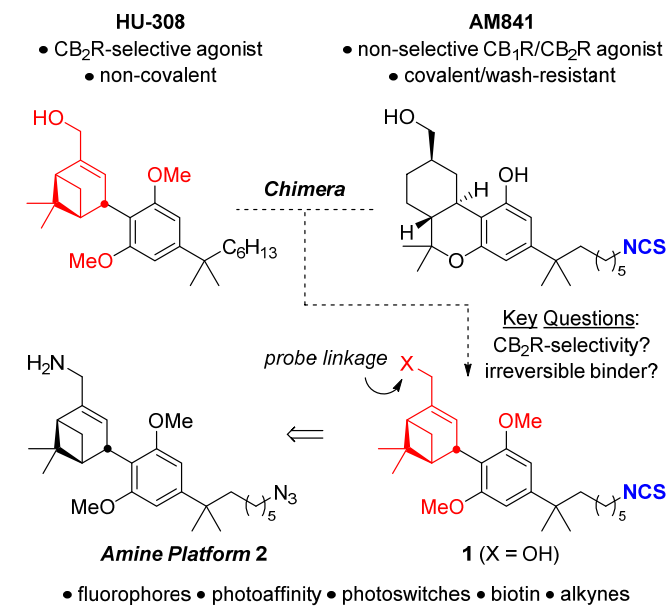

Figure 1. A hybrid of HU-308 and AM841 featuring structural elements responsible for $\mathrm{CB}_{2} \mathrm{R}$ selectivity (pinene core, capped phenol/resorcinol) and irreversible binding (isothiocyanate).

We hypothesized that hybrid structures derived from two prominent cannabinoid receptor ligands, namely HU-308 and $A M 841,{ }^{16,17}$ could serve as leads towards $C_{2} R$ selective covalent ligands (Figure 1). HU-308 is a full agonist of $\mathrm{CB}_{2} \mathrm{R}$ (cAMP assay: $\mathrm{hCB}_{2} \mathrm{R} \mathrm{EC} \mathrm{CC}_{50} \approx 6 \mathrm{nM}$ ) and 
has been appreciated for its high affinity $\left(\mathrm{hCB}_{2} \mathrm{R} \mathrm{K}_{\mathrm{i}} \approx\right.$ $20 \mathrm{nM}$ ) and pronounced selectivity over $\mathrm{CB}_{1} \mathrm{R}^{15,16}$ The compound features an aliphatic, primary hydroxyl group and an arene bearing an aliphatic sidechain. ${ }^{18}$ In contrast to classical cannabinoids as defined by the presence of a tricyclic benzochromene motif, $\mathrm{HU}-308$ is a pinene derivative lacking the central pyran. $\mathrm{HU}-308$ features two methyl ethers that were shown to be an important contributing factor to high $\mathrm{CB}_{2} \mathrm{R}$ selectivity. ${ }^{6}$ As a classical cannabinoid, AM841 includes a phenol along with a primary aliphatic alcohol. Its most notable feature is the electrophilic isothiocyanate at the terminus of the aliphatic sidechain, which can enable cross-linking of protein targets. ${ }^{21}$ AM841 is a full agonist of both $C B_{1} R$ and $C B_{2} R$ (cAMP assay: $\mathrm{hCB}_{1} \mathrm{R} \mathrm{EC}_{50} \approx 1 \mathrm{nM}, \mathrm{hCB}_{2} \mathrm{R} \mathrm{EC}_{50}<1 \mathrm{nM}$ ) and has been described as a ligand that binds irreversibly to both receptors on the basis of radioligand saturation binding studies $\left(\mathrm{CB}_{1} \mathrm{R} \text { and } \mathrm{CB}_{2} \mathrm{R}\right)^{4,8}$ as well as mass spectrometry-based proteomics $\left(\mathrm{CB}_{2} \mathrm{R}\right) .{ }^{9}$ In these studies, the authors concluded that Cys6.47 (BallesterosWeinstein numbering), ${ }^{24}$ a conserved amino acid present in both $\mathrm{CB}_{1} \mathrm{R}$ and $\mathrm{CB}_{2} \mathrm{R}$, forms covalent adducts with the electrophilic isothiocyanate of AM841. Surprisingly, a recent structure resulting from co-crystallization of $C_{1} R$ with AM841 shows the aliphatic sidechain of the latter pointing away from Cys6.47.25 While this observation renders a putative covalent adduct geometrically unlikely for $C_{1} R$, it is important to note that the situation may be different in the case of $\mathrm{CB}_{2} \mathrm{R}$, for which a covalent interaction with $\mathrm{AM} 841$ had been shown by mass spectrometry. ${ }^{22}$ Herein, we describe the design, synthesis and in vitro pharmacological evaluation of $1(\mathrm{X}=\mathrm{OH})$ and various derivatives, such as ethers and esters $(X=O R)$ as well as amides $(X=H N R)$. Our studies culminate in the identification of a privileged amine platform (2) for the modular preparation of highly selective $\mathrm{CB}_{2} \mathrm{R}$ agonists.

\section{Results and Discussion}

The synthesis of hybrid cannabinoid 1 featuring the pinene core and methyl ethers of $\mathrm{HU}-308$ as well as the electrophilic side chain of AM841 commenced with preparation of known resorcinol derivative 7 (Scheme 1). The published route towards 7 involves organolithium addition to Weinreb amide 3 (62\% yield), $\mathrm{TiMe}_{2} \mathrm{Cl}_{2}-$ mediated conversion of ketone 6 into the corresponding geminal dimethyl derivative as described by $\operatorname{Reetz}^{26}$ and subsequent global ether cleavage with $\mathrm{BBr}_{3}$ to afford 7 (84\% yield over two steps). ${ }^{27}$ We found that 6 could be conveniently prepared by $\mathrm{Fe}(\mathrm{acac})_{3}$ catalyzed cross coupling ${ }^{28}$ of readily available acyl chloride $\mathbf{4}$ and Grignard reagent $5^{29}$ in $90 \%$ yield $(\sim 12.3 \mathrm{~g})$. In our hands, subsequent conversion of ketone 6 into its geminal dimethyl derivative using $\mathrm{TiMe}_{2} \mathrm{Cl}_{2}$ (generated in situ from $\mathrm{TiCl}_{4}$ and $\mathrm{ZnMe}_{2}$ ) proceeded in $34 \%$ yield. ${ }^{30}$ Global ether cleavage according to $\mathrm{Tius}^{\prime} \mathrm{BBr}_{3}$ protocol ${ }^{27}$ proceeded cleanly as judged by thin layer chromatography. However, inspection of ${ }^{1} \mathrm{H}$ and ${ }^{13} \mathrm{C}$ NMR spectra revealed the presence of a side product identified as isomeric secondary alkyl bromide 7' amounting to ca. $10 \%$ of the material. The outcome of the last two steps prompted us to devise an alternative synthetic strategy towards resorcinol derivatives that would avoid the observed isomerization (vide infra).

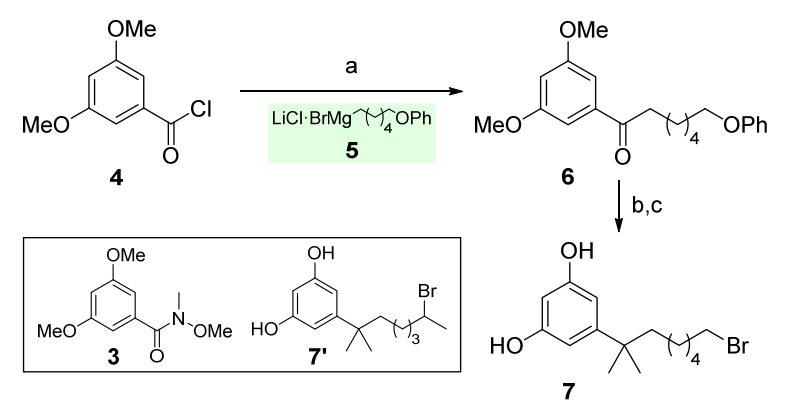

Scheme 1. Synthesis of resorcinol 7. Reagents and conditions: a) $\mathrm{Fe}(\mathrm{acac})_{3}(3 \mathrm{~mol} \%), \mathrm{THF},-78{ }^{\circ} \mathrm{C}, 90 \%$. b) $\mathrm{TiCl}_{4}, \mathrm{ZnMe}_{2}, \mathrm{CH}_{2} \mathrm{Cl}_{2},-30{ }^{\circ} \mathrm{C}$ to rt, $34 \%$. c) $\mathrm{BBr}_{3}, \mathrm{CH}_{2} \mathrm{Cl}_{2},-78{ }^{\circ} \mathrm{C}$ to rt, quantitative as inseparable mixture of 7 and secondary bromide 7 ' (ca. 9:1).

At this stage of the project, although the synthesis of 7 was suboptimal, we decided to venture ahead to collect initial pharmacological data. In analogy to the published synthesis of $\mathrm{HU}-308,{ }^{16}$ pTsOH-mediated Friedel-Crafts alkylation of 7 using allylic alcohol 8 derived from (+)- $\alpha-$ pinene followed by double methylation afforded 9 (Scheme 2). Ester reduction (DIBAL-H) and nucleophilic displacement of the derived alkyl bromide with sodium azide delivered 11 (93\% yield over both steps), which was further elaborated into 1. Alternatively, 11 was first propargylated prior to conversion of the azide to the corresponding isothiocyanate. The latter two-step sequence afforded bifunctional ligand 13 as putatively irreversible probe amenable to further derivatization for use in activity-based protein profiling experiments.

In a comparative study of HU-308 and its enantiomer HU433, the authors noted that the latter exhibited higher $\mathrm{CB}_{2} \mathrm{R}$-mediated biological activity than HU-308. This contrasted the expectation based on radioligand binding studies, which attested HU-308's higher $\mathrm{CB}_{2} \mathrm{R}$ affinity when compared to $\mathrm{HU}-433 .{ }^{31}$ Therefore, ent-1 was included in the present study in order to maximize the chance of identifying irreversible and selective $C_{2} R$ ligands. Compound ent-1 was accessed by Friedel-Crafts alkylation with ent-8 derived from (1R)-(-)-myrtenol and subsequent elaboration analogous to the sequence shown in Scheme 2 (see SI). 


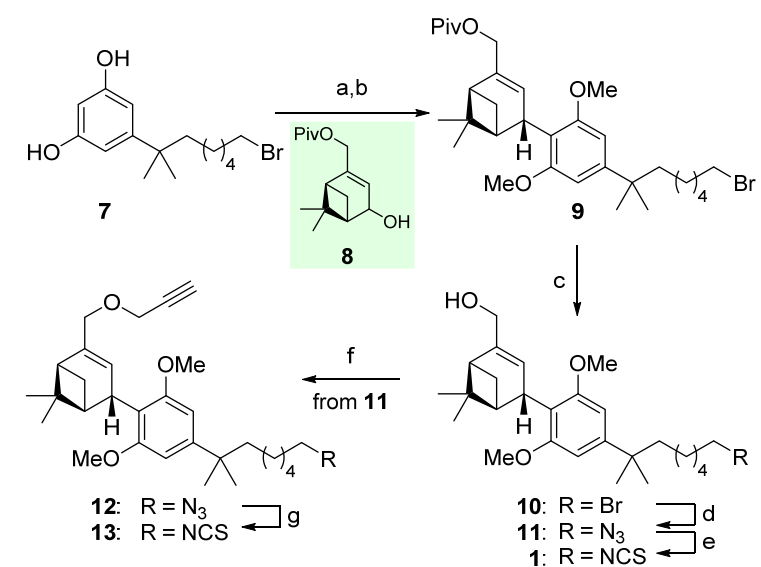

Scheme 2. Synthesis of electrophilic hybrid cannabinoids 1 and 13 . Reagents and conditions: a) $p \mathrm{TsOH} \cdot \mathrm{H}_{2} \mathrm{O}$ (0.28 equiv), $\mathrm{CH}_{2} \mathrm{Cl}_{2}, \mathrm{rt}, 86 \%$; b) $\mathrm{Me}_{2} \mathrm{SO}_{4}, \mathrm{~K}_{2} \mathrm{CO}_{3}$, acetone, rt, $73 \%$; c) DIBAL-H, $\mathrm{CH}_{2} \mathrm{Cl}_{2}, 0^{\circ} \mathrm{C}, 94 \%$; d) $\mathrm{NaN}_{3}$ DMF, rt, 99\%; e) $\mathrm{PPh}_{3}, \mathrm{CS}_{2}$, THF, rt, 84\%; f) propargyl bromide, $\mathrm{Bu}_{4} \mathrm{NHSO}_{4}$ ( 0.2 equiv), $50 \%$ aq. $\mathrm{NaOH}-\mathrm{PhMe}, \mathrm{rt}, 36 \%$; g) $\mathrm{PPh}_{3}, \mathrm{CS}_{2}, \mathrm{THF}, \mathrm{rt}, 81 \%$.

Drawing from a report on biotin-conjugated HU-308, in which elongation along the allylic alcohol was tolerated by $\mathrm{CB}_{2} \mathrm{R}^{32}$ fluorescent probe 15 was prepared by esterification of 1 with nitrobenzoxadiazole-derived acid 14 (Scheme 3). Since esters are prone to hydrolysis in biological environments, amide analogs of 15 were synthesized. To this end, amine 2 was prepared by a threestep sequence involving Mitsunobu reaction of allylic alcohol 10 with potassium phthalimide, bromide displacement with sodium azide and, finally, treatment with hydrazine. Subsequent amide formation and conversion of azide to isothiocyanate afforded fluorescent compounds 16 and 17 (see SI for fluorescence spectra).
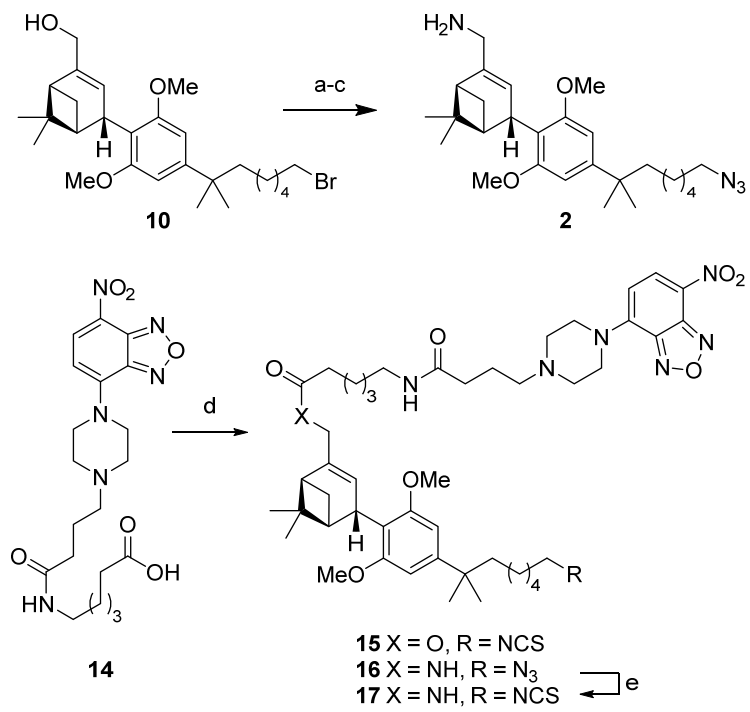

Scheme 3. Synthesis of amine 2 and fluorescent derivatives 15-17 Reagents and conditions: a) DIAD, $\mathrm{PPh}_{3}$, phthalimide, THF, rt, $62 \%$; b) $\mathrm{NaN}_{3}$, DMF, rt, $88 \%$; c) $\mathrm{N}_{2} \mathrm{H}_{4} \cdot \mathrm{H}_{2} \mathrm{O}$, crotyl alcohol, EtOH, $75^{\circ} \mathrm{C}, 73 \%$; d) fo 15: 1, EDC $\cdot \mathrm{HCl}, \mathrm{DMAP}, \mathrm{NEt}_{3}, \mathrm{THF}, \mathrm{rt}, 90 \%$; for 16: 2, EDC $\cdot \mathrm{HCl}, \mathrm{NEt}_{3}, \mathrm{THF}$ rt, $56 \%$; e) $\mathrm{PPh}_{3}, \mathrm{CS}_{2}, \mathrm{THF}, \mathrm{rt}, 74 \%$.

In vitro pharmacological assessment of prepared compounds (vide infra) showed that amide derivatives 16 and 17 exhibited significantly increased binding affinity to $\mathrm{hCB}{ }_{2} \mathrm{R}$ compared to ester 15 , as well as sharply increased selectivity over $h \mathrm{hB}_{1} \mathrm{R}$. Interestingly, cannabinoids in which the primary alcohol is replaced by amines and their derivatives have not been studied in detail. The few examples include an acetamide derivative of $\Delta^{8}$ tetrahydrocannabinol $\left(\Delta^{8}-\mathrm{THC}\right)$ reported to be analgesically inactive ${ }^{33}$ and more recent studies of fluorescent probes for the cannabinoid receptors. ${ }^{34,35} \mathrm{~A}$ small number of amine analogs was evaluated in mice ${ }^{36}$ and baboons, ${ }^{37}$ but since these studies predate the discovery and cloning of cannabinoid receptors, no data on binding affinities are available. The apparent lack of structure-activity information and the observed high $\mathrm{CB}_{2} \mathrm{R}$ affinity of ligands bearing the underexplored amide linkage prompted us to devise a concise synthetic strategy towards amide derivatives of HU-308. In addition, an expedient route to resorcinol derivatives that a) avoids contamination with constitutional isomers and b) allows for introduction of other functionalities in the side chain was developed (Scheme 4). The latter is of special interest regarding incorporation of polar functional groups to effect reduction of non-specific binding, an issue known to correlate with lipophilicity $(\log D) .{ }^{38}$
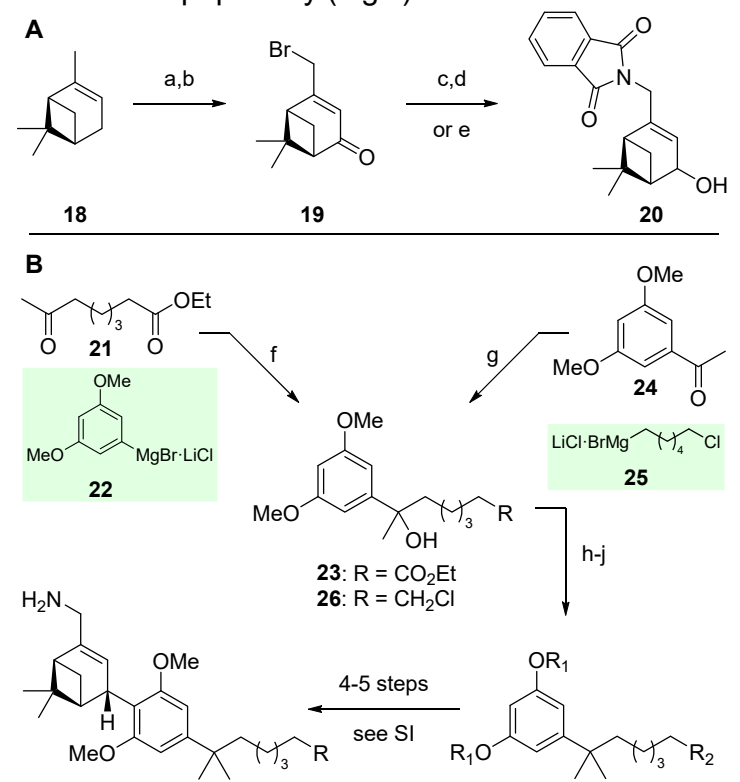

$$
\begin{aligned}
& \text { 2: } \mathrm{R}=\mathrm{CH}_{2} \mathrm{~N}_{3} \quad \text { 27: } \mathrm{R}_{1}=\mathrm{Me}, \mathrm{R}_{2}=\mathrm{CO}_{2} \mathrm{Et} \\
& \text { 31: } \mathrm{R}=\mathrm{CONH}_{2} \\
& \text { 32: } \mathrm{R}=\mathrm{CH}_{3}
\end{aligned}
$$

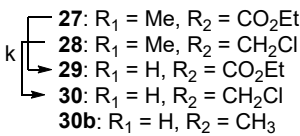

Scheme 4. A) Synthesis of $\mathrm{N}$-protected allylic alcohol. Reagents and conditions: a) $\mathrm{CrO}_{3}, \mathrm{~N}$-hydroxyphthalimide, acetone, rt, 44\%; b) NBS, dibenzoyl peroxide, $\mathrm{CCl}_{4}$, reflux, $62 \%$; c) potassium phthalimide, DMF, rt, $85 \%$; d) $\mathrm{CeCl}_{3} \cdot 7 \mathrm{H}_{2} \mathrm{O}, \mathrm{NaBH}_{4}, \mathrm{MeOH},-78{ }^{\circ} \mathrm{C}, 93 \%$; e) DIBAL-H, Et $2 \mathrm{O}-$ hexanes; then acidic workup; then potassium phthalimide, DMSO, rt, $77 \%$ over 2 steps. B) Synthesis of resorcinol derivatives and further elaboration into allyl amines. Reagents and conditions: f) 22 , THF, $-78{ }^{\circ} \mathrm{C}$ to $\mathrm{rt}, 92 \%$; g) 25 , THF, $-78{ }^{\circ} \mathrm{C}$ to rt, $60 \%$; h) for $22: \mathrm{SOCl}_{2}, 0{ }^{\circ} \mathrm{C}$; for $28: \mathrm{HCl}$ conc., rt; i) $\mathrm{AlMe}_{3}, \mathrm{CH}_{2} \mathrm{Cl}_{2},-78{ }^{\circ} \mathrm{C}$ to rt; j) $\mathrm{OsO}_{4}$ (cat.), oxone, DMF, rt, for 27: $42 \%$ from 23, for 28: $67 \%$ from 26; k) $\mathrm{BBr}_{3}, \mathrm{CH}_{2} \mathrm{Cl}_{2},-78{ }^{\circ} \mathrm{C}$ to rt, $97 \%(29), 93 \%$ (28). 
Following a patent procedure, (+)- $\alpha$-pinene (18) was oxidized to verbenone by $\mathrm{CrO}_{3}$ in presence of $\mathrm{N}$ hydroxyphthalimide. ${ }^{39}$ Subsequent allylic bromination under Wohl-Ziegler conditions afforded 19. The two-step sequence involving bromide displacement and ketone reduction could be carried out in either order, although it proved convenient to first reduce ketone 19 and then subject the product bromide to displacement by azide. This order of events yielded allyl alcohol 20 in $77 \%$ yield over two steps and avoided capricious chemoselective ketone reduction in presence of phthalimide under Luche conditions.

The revised resorcinol synthesis commenced with addition of Grignard reagent 22 to ketoester $21 .{ }^{40}$ Alternatively, 25 was added to ketone 24 . The resulting tertiary alcohols 23 and 26 were converted into their gem-dimethyl derivatives by modification of a reported procedure. ${ }^{41}$ First, treatment with $\mathrm{SOCl}_{2}$ (for 23 ) or conc. $\mathrm{HCl}$ (for 26 ) resulted in formation of the corresponding tertiary chlorides, which without purification were treated with $\mathrm{AlMe}_{3}$ to install the gem-dimethyl group. The unpurified mixtures were subjected to oxone/cat. $\mathrm{OsO}_{4}$ to effect oxidative degradation of the otherwise inseparable olefin byproducts (ca. 10\%) formed by elimination of the tertiary alcohol over the course of installation of the gem-dimethyl group. ${ }^{42}$ This procedure allowed for convenient isolation of the desired dimethyl resorcinols 27 and $28(67 \%$ and $42 \%$ yield, respectively. Cleavage of the methyl ethers with $\mathrm{BBr}_{3}$ cleanly afforded resorcinols 29 (93\% yield) and $\mathbf{3 0}$ (97\% yield) with no detectable formation of constitutional isomers. Each of these was then allowed to react with 20 and further elaborated into amines 2, 31 and $\mathbf{3 2}$ following the logic outlined in Scheme 2 (see SI). Additionally, known resorcinol $\mathbf{3 0 b}$ was subjected to the same sequence to afford 32 . It is worth noting that THC derivatives bearing a terminal carboxylate in the side chain have been employed as haptens for antibody generation. ${ }^{43}$

With allylic amines 2, 31, and 32 in hand, straightforward derivatization reactions afforded a number of aza-HU-308 derivatives shown in Figure 2. Probes 33-35, which may be activated upon irradiation, ${ }^{44}$ were synthesized by amidation of the corresponding amines $(2,31$, and 32$)$ and recently applied in a study on $\mathrm{CB}_{2} \mathrm{R}$ photoaffinitylabeling. ${ }^{45}$ In this work, $\mathbf{3 3}$ successfully labelled the receptor upon irradiation $(350 \mathrm{~nm})$ as shown by in-gel fluorescence following fluorophore attachment.

Conjugation of 4-pentynoic acid and subsequent triazole formation with 1-azidoadamantane afforded compounds $\mathbf{3 6}$ and $\mathbf{3 7}$. Amide $\mathbf{3 8}$ and sulfonamide $\mathbf{3 9}$ were prepared by condensation reactions with biotin and 1-butanesulfonyl chloride, respectively. Amide formation with tetra-orthochloro-azobenzene containing fatty acid FAAzo4 ${ }^{46}$ afforded photoswitch $\mathbf{4 0}$ and completed the set of aminederived compounds tested in this study.

In vitro pharmacological characterization. All synthesized compounds were evaluated in radioligand binding studies with tritiated CP55,940 using membrane preparations of Chinese hamster ovary $(\mathrm{CHO})$ cells overexpressing $\mathrm{CB}_{2} \mathrm{R}$ (human and mouse) or human $C_{1} R$, respectively. All experiments were run using aliquots of the same batches of isolated $\mathrm{CHO}-m e m b r a n e s$ expressing the respective receptor. In addition, widely used cyclic adenosine monophosphate (cAMP) assay was employed as described earlier ${ }^{47}$ to assess functional activity of prepared HU-308 derivatives. Results are listed in Table 1.<smiles>C#CCCC1(CCC(=O)NCC2=C[C@H](c3c(OC)cc(C(C)(C)CCCN)cc3OC)[C@@H]3CC2C3(C)C)N=N1</smiles>

33

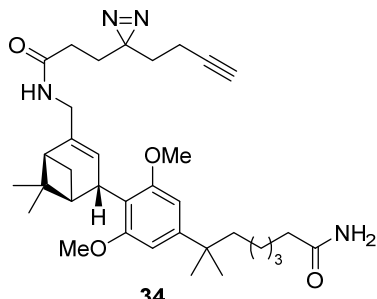

34<smiles>[Y4]CC(C)(C)c1cc(OC)c(C2C3C=C(CNC(=O)CCC4(CCC#C)N=N4)C(C3)C2(C)C)c(OC)c1</smiles>

35

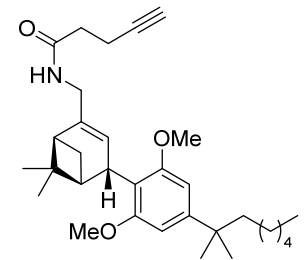

36<smiles>CCCC(C)(C)c1cc(OC)c(C23C=C(CNC(=O)CCc4cn(C56CC7CC(CC(C7)C5)C6)nn4)C(C2)C3(C)C)c(OC)c1</smiles>

37

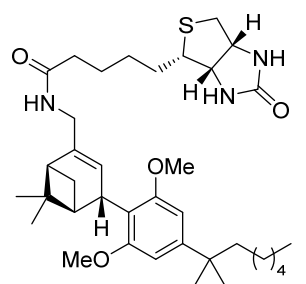

38

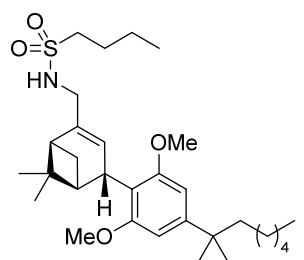

39

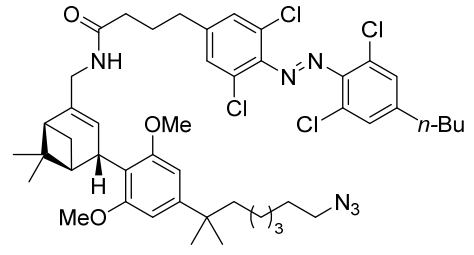

40

Figure 2. Additional aza-HU-308 derivatives tested in this study. Compounds were prepared by condensation reactions of the corresponding allylic amines. $\mathbf{3 7}$ was synthesized from $\mathbf{3 6}$ by copper-catalyzed cycloaddition. See SI for experimental details. 
Compounds 1, 10 and 11 share the free allylic alcohol and exhibit distinct groups terminating the dimethylheptyl chain. These compounds emerged as high affinity $h \mathrm{hCB}_{2} \mathrm{R}$ binders $\left(\mathrm{K}_{\mathrm{i}} \mathrm{hCB} \mathrm{B}_{2} \mathrm{R}<13 \mathrm{nM}\right)$ with at least 86 -fold selectivity over $h \mathrm{CB}_{1} \mathrm{R}$. In line with Mechoulam's report, ${ }^{31}$ compounds ent-1, ent-10-Cl and ent-11 showed lower $h \mathrm{CB}_{2} \mathrm{R}$ affinity than their enantiomers by a factor of ca. 10 $\left(\mathrm{hCB}{ }_{2} \mathrm{R} \mathrm{K}_{\mathrm{i}}<121 \mathrm{nM}\right)$ but retained high selectivity over $h \mathrm{hB}_{1} \mathrm{R} \quad\left(\mathrm{hCB} \mathrm{B}_{1} \mathrm{R} \mathrm{K}_{\mathrm{i}}>3.1 \mu \mathrm{M}\right)$. Nitrobenzofurazan-derived compounds 15-17 were identified as highly promising $\mathrm{hCB}{ }_{2} \mathrm{R}$-selective fluorescent probes given their complete selectivity over $\mathrm{CB}_{1} \mathrm{R}$. Importantly, exchanging the potentially vulnerable ester functionality in $\mathbf{1 5}$ for an amide linkage resulted in analogs 16 and 17 with significantly increased $C_{2} R$ affinity and remarkable selectivity over $\mathrm{CB}_{1} \mathrm{R}$ (ratio $h \mathrm{hCB}_{1} \mathrm{R} \mathrm{K}_{\mathrm{i}} / \mathrm{hCB}_{2} \mathrm{R} \mathrm{K}_{\mathrm{i}}>2000$ ). The primary amide in $\mathbf{3 5}$ proved detrimental to receptor selectivity. Comparing compounds 33-35 differing only in the side chain, the terminal azide emerged as most favorable for achieving high $\mathrm{hCB}_{2} \mathrm{R}$-selectivity. Introduction of said terminal azide (33) results in ca. 10-fold increase in selectivity compared to its saturated analog $35 .{ }^{35}$ Adamantyl-substituted triazole and biotin derivatives 37 and 38 exhibited decreased $\mathrm{hCB}_{2} \mathrm{R}$ affinity along with low selectivity over $h \mathrm{hB}_{1} \mathrm{R}$. Sulfonamide 39 showed affinity comparable to 35 , while azobenzene derivative $\mathbf{4 0}$ (as undefined mixture of trans- and cis-isomers) was found to be a $\mathrm{hCB}_{2} \mathrm{R}$-selective high-affinity ligand. Interestingly, all compounds tested showed a preference for human $\mathrm{CB}_{2} \mathrm{R}$ over the mouse isoform. Human and mouse $\mathrm{CB}_{2} \mathrm{R}$ share $86 \%$ sequence identity within the ligand binding domain differing only in amino acids 72 and 261 . While $\mathrm{hCB}_{2} \mathrm{R}$ contains amino acids Ser72 and Val261, $\mathrm{mCB}_{2} \mathrm{R}$ displays Asn72 and Ala261 residues. These alterations seem to create a binding pocket less effective in accommodating HU-308 derivatives.

In the functional cAMP assay, all compounds were identified as full agonists of both human and mouse $C_{2} R$ with relative $\mathrm{EC}_{50}$ values resembling the trends observed in the radioligand binding assay, albeit not as pronounced. With the exception of 10,11 and to some extent 40 , all compounds bearing a terminal NCS or $\mathrm{N}_{3}$ group were functionally inactive at $\mathrm{hCB}_{1} \mathrm{R}$ (12: partial $\mathrm{hCB}_{1} \mathrm{R}$ agonist with $58 \%$ efficacy and $\left.\mathrm{hCB}_{1} \mathrm{R} \mathrm{EC}_{50} \approx 1.4 \mu \mathrm{M}\right)$. Comparison of compounds 15 and 17 shows that the higher binding affinity of amide $\mathbf{1 7}$ also translates into higher potency in cAMP assay for both human and mouse $C_{2} R$. 
Table 1. In vitro pharmacological assessment of $\mathrm{HU}-308$ derivatives. ${ }^{\text {[a] }}$<smiles>[R]CCCC(C)(C)c1cc(OC)c(C23CCC(CC)(CC2(C)C)C3)c(OC)c1</smiles>

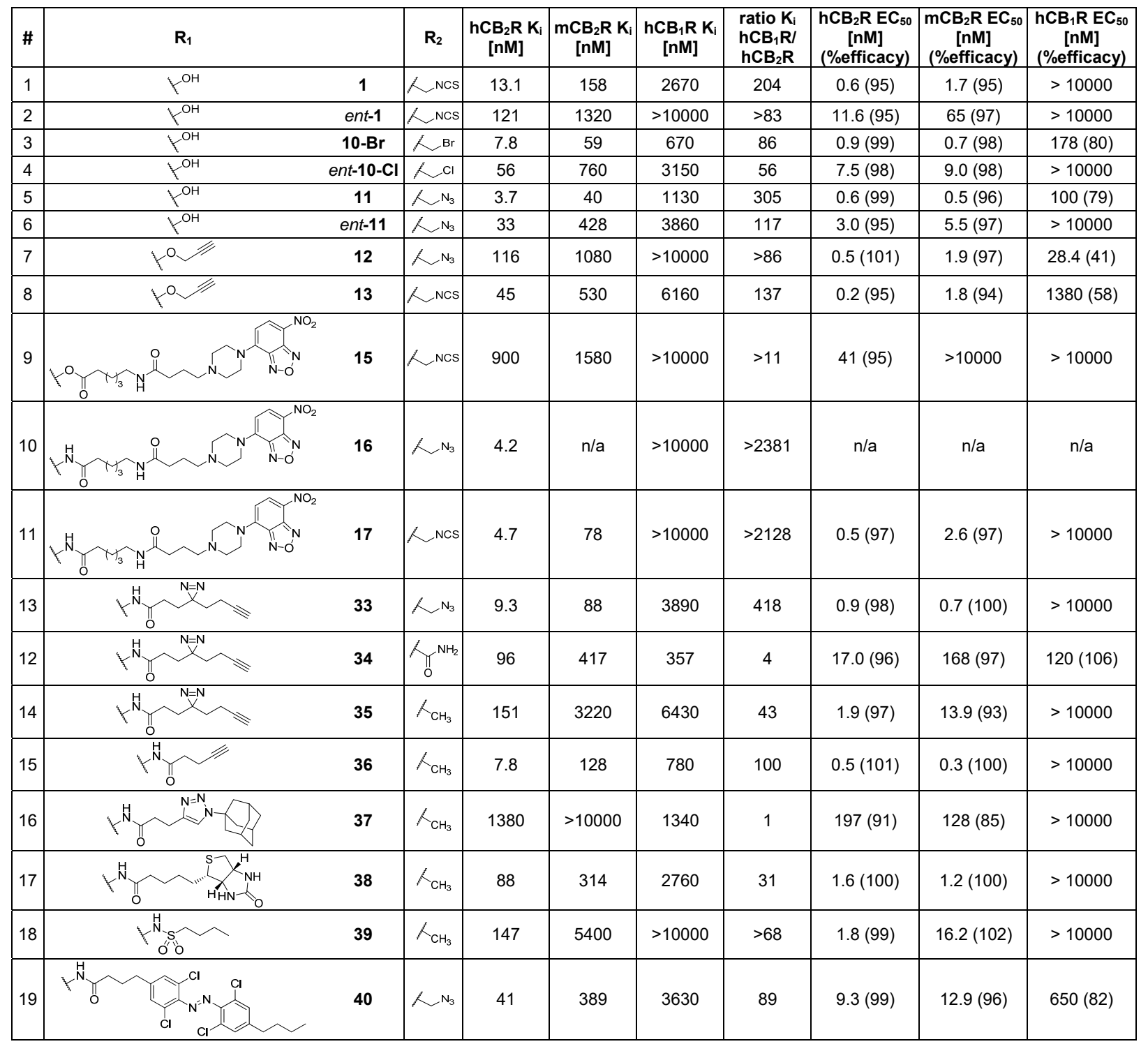

[a] Dissociation constants $(\mathrm{Ki})$ were determined by radioligand binding assay using membrane preparations of $\mathrm{CB}_{1} \mathrm{R} / \mathrm{CB}_{2} \mathrm{R}$ overexpressing $\mathrm{CHO}$ cells with $\left[{ }^{3} \mathrm{H}\right]-\mathrm{CP} 55,940$ as described previously and are given as average values from one up to six independent experiments each performed in triplicate. cAMP assays were performed with $\mathrm{CHO}$ cells expressing human $\mathrm{CB}_{1} \mathrm{R}$ and $\mathrm{CB}_{2} \mathrm{R}$ receptor variants as described. ${ }^{47}$ Efficacies are expressed as percentages relative to the effect evoked by CP55,940 $(1 \mu \mathrm{M})$. EC 50 values are averages from one to two independent experiments each performed in triplicate.

Docking studies. Docking agonist 17 into the recently compared to ester 15 . The hypothesis is further published $\mathrm{X}$-ray crystal structure of antagonist bound corroborated by pairwise comparison of compounds $\mathbf{1 1 / 1 2}$ $\mathrm{CB}_{2} \mathrm{R}$ (PDB code: $\left.5 \mathrm{ZTY}\right)^{48}$ suggests a favorable hydrogen and 1/13. In both cases, analogs bearing a free hydroxy bond between the amide group of $17(\mathrm{~N}-\mathrm{H}$ as $\mathrm{H}$-bond group as potential $\mathrm{H}$-bond donor (1, 11) exhibit higher donor) and the carbonyl of Ser72 (H-bond acceptor) binding affinity than the corresponding propargyl ether (Figure 3). This finding may explain the observed analogs $(12,13)$. increased binding affinity of 17 (and other amide analogs) 


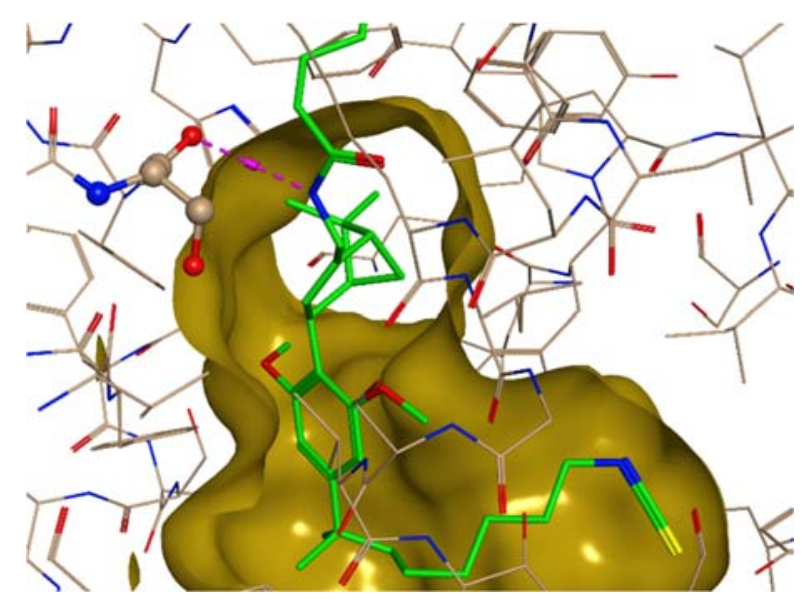

Figure 3 Docking pose of 17 within the crystal structure of $\mathrm{CB}_{2} \mathrm{R}$ determined in complex with antagonist AM10257 (PDB code: 5ZTY). The model suggests formation of a hydrogen bond (magenta) between 17 and Ser72 (bold ribbon).

Probing for irreversible binding. Earlier reports describe saturation binding experiments to show AM841's ability to covalently bind both $\mathrm{CB}_{1} \mathrm{R}$ and $\mathrm{CB}_{2} \mathrm{R}$ via Cys6.47. ${ }^{17,23}$ In these experiments, membranes expressing wildtype $C_{1} R$ and $\mathrm{CB}_{2} \mathrm{R}$ were preincubated with $\mathrm{AM} 841$ or DMSO control. Following excessive washing steps, saturation binding experiments with tritiated CP55,940 revealed decreased receptor density $\left(B_{\max }\right)$ for pretreated membranes compared to control. In addition, performing the same experiment with receptor variants in which Cys6.47 was mutated to serine, alanine or leucine did not show reduction of $B_{\max }$ when comparing pretreated membranes to control. As orthosteric covalent binders are expected to reduce the number of available binding sites, these observations led to the conclusion that $A M 841$ is an irreversible binder of both $\mathrm{CB}_{1} \mathrm{R}$ and $\mathrm{CB}_{2} \mathrm{R}$.

In analogy, we proceeded to evaluate compounds 1 and ent-1 for their ability to reduce $B_{\max }$. To this end membrane preparations of $\mathrm{hCB}_{2} \mathrm{R}$-overexpressing $\mathrm{CHO}$ cells were incubated with DMSO control or putatively covalent compounds 1 (90 nM) and ent-1 (790 nM) at concentrations corresponding to ca. 6-fold $\mathrm{K}_{\mathrm{i}}$ for 60 minutes. Following excessive washing steps to remove non-covalently bound material, determination of receptor density $\left(B_{\max }\right)$ using tritiated CP55,940 would allow for indirect proof of irreversible bond formation for orthosteric ligands. As shown in Figure 4, saturation binding of $\left[{ }^{3} \mathrm{H}\right]-$ CP55,940 using membranes preincubated with 1 or DMSO (Figure 4A), and ent-1 or DMSO (Figure 4B) revealed similar maximum specific binding $\left(B_{\max }\right)$ within either set of experiments. Thus, 1 and ent-1 are not considered irreversible, orthosteric ligands of $h \mathrm{hCB}_{2} \mathrm{R}$. This outcome is in line with a separate experiment aiming to detect covalent bond formation of fluorescent electrophilic ligand 17. In this experiment, membranes of $\mathrm{hCB}_{2} \mathrm{R}$ overexpressing $\mathrm{CHO}$-cells were incubated with 17 (up to
$10 \mu \mathrm{M})$. When proteins of the sample were resolved by polyacrylamide gel electrophoresis, no fluorescent band corresponding to $\mathrm{CB}_{2} \mathrm{R}$ protein was detected.
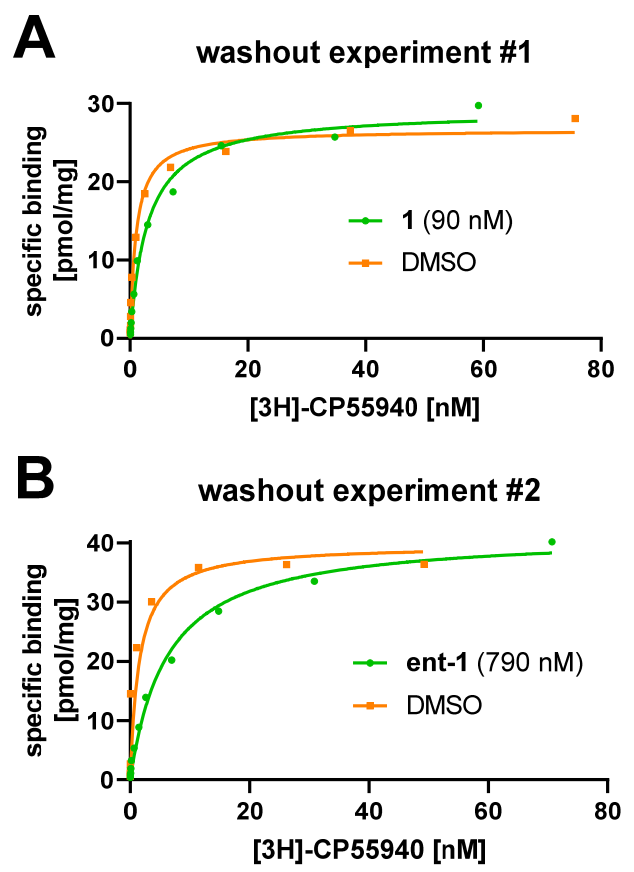

Figure 4 Washout experiments probing for irreversible binding. Saturation binding of $\left[{ }^{3} \mathrm{H}\right]-\mathrm{CP} 55,940$. Specific binding in dependence on radioligand concentration determined using membranes pretreated with $6 \times \mathrm{K}_{i}$ of ligands 1, ent-1 or DMSO.

\section{Conclusions}

Enabled by a practical synthesis of functionalized resorcinols, the amine derivatives identified in this study allow modular and convenient access to highly $\mathrm{CB}_{2} \mathrm{R}$ selective ligands. Conjugates prepared from amine 13 in particular, bearing a terminal azide in the dimethylheptyl side chain, emerged as ligands with the highest affinity and selectivity for $h \mathrm{CB}_{2} \mathrm{R}$ across the series. The promise of this approach is showcased by the synthesis of various functional $\mathrm{CB}_{2} \mathrm{R}$ ligands, most notably fluorescent probe 16. This exceptionally selective fluoroprobe binds $h \mathrm{hCB}_{2} R$ with a $\mathrm{K}_{\mathrm{i}}$ of $4 \mathrm{nM}$ as determined by radioligand binding assay and shows no detectable interaction with $\mathrm{hCB}_{1} \mathrm{R}$. Thus, our initial quest for selective $C_{2} R$ ligands that bind irreversibly by merging structural motifs found in HU-308 and AM841 afforded useful hybrid cannabinoids of type 1 and its enantiomer ent-1. However, studies of these ligands and their derivatives do not support the formation of covalent adducts to $\mathrm{CB}_{2} \mathrm{R}$.

Docking studies using the recently published crystal structure of inactive state $\mathrm{hCB}_{2} \mathrm{R}$ suggest the marked affinity of the amide analogs is due to a hydrogen bond between the amide $\mathrm{N}-\mathrm{H}$ and Ser72, which is not available to the corresponding ester derivatives. Interestingly, the chemotype presented displays intrinsic preference for 
human $\mathrm{CB}_{2} \mathrm{R}$ over the mouse isoform. This finding is important in the light of transferability of preclinical in vivo data generated using commonly employed mouse models.

We believe the in vitro pharmacological data presented for amide derivatives of HU-308 is a valuable addition to the structure-activity-relationship knowledge of cannabinoids. Our work serves as blueprint for the preparation of selective $\mathrm{CB}_{2} \mathrm{R}$ ligands, incorporating functional elements tailored to a given biological experiment. Ongoing work in our laboratories focuses on additional applications of the ligands described and will be reported as results become available.

\section{Acknowledgements}

EMC is grateful to ETH-Zürich and F. Hoffmann-La Roche for support of the research program. We thank Prof. James Frank for providing a sample of FAAzo4 and Dr. Marjolein Soethoudt for evaluation of electrophilic fluoroprobe 17. Dr. Sylwia Huber, Eric Kusznir and Dr. Arne Rufer are gratefully acknowledged for the generation of absorption, excitation and emission spectra.

Keywords: cannabinoid receptor $2 \cdot \mathrm{CB}_{2} \mathrm{R} \cdot$ electrophilic ligands - fluorescent probe • chemical probe • endocannabinoid system

1 Y. Gaoni, R. Mechoulam, J. Am. Chem. Soc. 1964, 86, 1646.

2 D. Piomelli, Nat. Rev. Neurosci. 2003, 4, 873.

3 V. D. Marzo, M. Bifulco, L. D. Petrocellis, Nat. Rev. Drug Discov. 2004, 3, 771.

4 R. Mechoulam, L. A. Parker, Annu. Rev. Psychol. 2013, 64, 21.

5 P. Pacher, S. Bátkai, G. Kunos, Pharmacol. Rev. 2006, 58 389.

6 M. Maccarrone, I. Bab, T. Bíró, G. A. Cabral, S. K. Dey, V. Di Marzo, J. C. Konje, G. Kunos, R. Mechoulam, P. Pacher, K. A. Sharkey, A. Zimmer, Trends Pharmacol. Sci. 2015, 36, 277.

7 Atwood Brady K, Mackie Ken, Br. J. Pharmacol. 2010 $160,467$.

8 A. López, N. Aparicio, M. R. Pazos, M. T. Grande, M. A. Barreda-Manso, I. Benito-Cuesta, C. Vázquez, M. Amores, G. Ruiz-Pérez, E. García-García, M. Beatka, R. M. Tolón, B. N. Dittel, C. J. Hillard, J. Romero, J. Neuroinflammation 2018, 15, 158.

9 Y. Marchalant, P. W. Brownjohn, A. Bonnet, T. Kleffmann, J. C. Ashton, J. Histochem. Cytochem. 2014, 62, 395.

10 C. H. Arrowsmith, J. E. Audia, C. Austin, J. Baell, J. Bennett, J. Blagg, C. Bountra, P. E. Brennan, P. J. Brown, M. E. Bunnage, C. Buser-Doepner, R. M. Campbell, A. J. Carter, P. Cohen, R. A. Copeland, B. Cravatt, J. L. Dahlin, D. Dhanak, A. M. Edwards, M. Frederiksen, S. V. Frye, N. Gray, C. E. Grimshaw, D. Hepworth, T. Howe, K. V. M. Huber, J. Jin, S. Knapp, J. D. Kotz, R. G. Kruger, D. Lowe, M. M. Mader, B. Marsden, A. Mueller-Fahrnow, S. Müller, R. C. O'Hagan, J. P. Overington, D. R. Owen, S. H. Rosenberg, R. Ross, B. Roth, M. Schapira, S. L.
Schreiber, B. Shoichet, M. Sundström, G. Superti-Furga, J. Taunton, L. Toledo-Sherman, C. Walpole, M. A. Walters, T. M. Willson, P. Workman, R. N. Young, W. J. Zuercher, Nat. Chem. Biol. 2015, 11, 536.

11 B. F. Cravatt, A. T. Wright, J. W. Kozarich, Annu. Rev. Biochem. 2008, 77, 383.

12 P. Kleiner, W. Heydenreuter, M. Stahl, V. S. Korotkov, S. A. Sieber, Angew. Chem. Int. Ed. 2017, 56, 1396.

13 M. Toure, C. M. Crews, Angew. Chem. Int. Ed. 2016, 55, 1966.

14 L. Zhou, L. M. Bohn, Curr. Opin. Cell Biol. 2014, 27, 102.

15 M. Soethoudt, U. Grether, J. Fingerle, T. W. Grim, F. Fezza, L. de Petrocellis, C. Ullmer, B. Rothenhäusler, C. Perret, N. van Gils, D. Finlay, C. MacDonald, A. Chicca, M. D. Gens, J. Stuart, H. de Vries, N. Mastrangelo, L. Xia, G. Alachouzos, M. P. Baggelaar, A. Martella, E. D. Mock, H. Deng, L. H. Heitman, M. Connor, V. Di Marzo, J. Gertsch, A. H. Lichtman, M. Maccarrone, P. Pacher, M. Glass, M. van der Stelt, Nat. Commun. 2017, 8, 13958.

16 L. Hanuš, A. Breuer, S. Tchilibon, S. Shiloah, D. Goldenberg, M. Horowitz, R. G. Pertwee, R. A. Ross, R. Mechoulam, E. Fride, PNAS 1999, 96, 14228.

17 R. P. Picone, A. D. Khanolkar, W. Xu, L. A. Ayotte, G. A. Thakur, D. P. Hurst, M. E. Abood, P. H. Reggio, D. J. Fournier, A. Makriyannis, Mol. Pharmacol. 2005, 68, 1623.

18 G. A. Thakur, S. P. Nikas, C. Li, A. Makriyannis, in Cannabinoids, R. G. Pertwee (editor), Springer Berlin Heidelberg, 2005, 209.

19 J. W. Huffman, J. Liddle, S. Yu, M. M. Aung, M. E. Abood, J. L. Wiley, B. R. Martin, Bioorg. Med. Chem. 1999, 7, 2905.

20 J. W. Huffman, S. Yu, V. Showalter, M. E. Abood, J. L. Wiley, D. R. Compton, B. R. Martin, R. D. Bramblett, P. H. Reggio, J. Med. Chem. 1996, 39, 3875.

21 D. Weichert, P. Gmeiner, ACS Chem. Biol. 2015, 10, 1376.

22 D. W. Szymanski, M. Papanastasiou, K. Melchior, N. Zvonok, R. W. Mercier, D. R. Janero, G. A. Thakur, S. Cha, B. Wu, B. Karger, A. Makriyannis, J. Proteome Res. 2011, 10, 4789 .

23 Y. Pei, R. W. Mercier, J. K. Anday, G. A. Thakur, A. M. Zvonok, D. Hurst, P. H. Reggio, D. R. Janero, A. Makriyannis, Chem. Biol. 2008, 15, 1207.

$24 \mathrm{~J}$. A. Ballesteros, $H$. Weinstein, in Methods in Neurosciences, S. C. Sealfon (editor), Academic Press, 1995, Vol. 25, pp. 366.

25 T. Hua, K. Vemuri, S. P. Nikas, R. B. Laprairie, Y. Wu, L. Qu, M. Pu, A. Korde, S. Jiang, J.-H. Ho, G. W. Han, K. Ding, X. Li, H. Liu, M. A. Hanson, S. Zhao, L. M. Bohn, A. Makriyannis, R. C. Stevens, Z.-J. Liu, Nature 2017, 547, 468.

26 Reetz Manfred T., Westermann Jürgen, Kyung Suk-Hun, Chem. Ber. 1985, 118, 1050.

27 M. A. Tius, Chem. Commun. 1997, 1867.

28 B. Scheiper, M. Bonnekessel, H. Krause, A. Fürstner, J. Org. Chem. 2004, 69, 3943.

29 F. M. Piller, P. Appukkuttan, A. Gavryushin, M. Helm, P. Knochel, Angew. Chem. Int. Ed. 2008, 47, 6802.

30 C. Chu, A. Ramamurthy, A. Makriyannis, M. A. Tius, J. Org. Chem. 2003, 68, 55. 
31 R. Smoum, S. Baraghithy, M. Chourasia, A. Breuer, N. Mussai, M. Attar-Namdar, N. M. Kogan, B. Raphael, D. Bolognini, M. G. Cascio, P. Marini, R. G. Pertwee, A. Shurki, R. Mechoulam, I. Bab, PNAS 2015, 112, 8774.

32 L. Martín-Couce, M. Martín-Fontecha, Ó. Palomares, L. Mestre, A. Cordomí, M. Hernangomez, S. Palma, L. Pardo, C. Guaza, M. L. López-Rodríguez, S. OrtegaGutiérrez, Angew. Chem. Int. Ed. 2012, 51, 6896.

33 R. S. Wilson, B. R. Martin, W. L. Dewey, J. Med. Chem. 1979, 22, 879.

34 M. Martín-Fontecha, A. Angelina, B. Rückert, A. RuedaZubiaurre, L. Martín-Cruz, W. van de Veen, M. Akdis, S. Ortega-Gutiérrez, M. L. López-Rodríguez, C. A. Akdis, O. Palomares, Bioconjugate Chem. 2018, 29, 382.

35 A. R. Zubiaurre, Chemical Probes for the Study of the Endogenous Cannabinoid System, PhD Thesis, Complutense University of Madrid, 2015.

36 D. R. Compton, P. J. Little, B. R. Martin, J. W. Gilman, J. K. Saha, V. S. Jorapur, H. P. Sard, R. K. Razdan, J. Med. Chem. 1990, 33, 1437.

37 H. Edery, G. Porath, R. Mechoulam, N. Lander, M. Srebnik, N. Lewis, J. Med. Chem. 1984, 27, 1370.

38 S. Nagar, K. Korzekwa, Drug. Metab. Dispos. 2012, 40, 1649.

39 P. Marwah, H. A. Lardy, 1999, US Patent US6384251B1.

40 Biswas Srijit, Maiti Sukhendu, Jana Umasish, Europ. J. Org. Chem. 2010, 2010, 2861.

41 J. A. Hartsel, D. T. Craft, Q.-H. Chen, M. Ma, P. R. Carlier, J. Org. Chem. 2012, 77, 3127.

42 B. R. Travis, R. S. Narayan, B. Borhan, J. Am. Chem. Soc. 2002, 124, 3824.

43 L. Qi, N. Yamamoto, M. M. Meijler, L. J. Altobell, G. F. Koob, P. Wirsching, K. D. Janda, J. Med. Chem. 2005, 48, 7389.

44 Z. Li, P. Hao, L. Li, C. Y. J. Tan, X. Cheng, G. Y. J. Chen, S. K. Sze, H.-M. Shen, S. Q. Yao, Angew. Chem. Int. Ed. 2013, 52, 8551.

45 M. Soethoudt, S. C. Stolze, M. V. Westphal, L. van Stralen, A. Martella, E. J. van Rooden, W. Guba, Z. V. Varga, H. Deng, S. I. van Kasteren, U. Grether, A. P. IJzerman, P. Pacher, E. M. Carreira, H. S. Overkleeft, A. Ioan-Facsinay, L. H. Heitman, M. van der Stelt, J. Am. Chem. Soc. 2018, 140, 6067.

46 J. A. Frank, M. Moroni, R. Moshourab, M. Sumser, G. R. Lewin, D. Trauner, Nature Commun. 2015, 6, 7118.

47 C. Ullmer, S. Zoffmann, B. Bohrmann, H. Matile, L. Lindemann, P. J. Flor, P. Malherbe, Br. J. Pharmacol. 2012, 167, 1448.

48 X. Li, T. Hua, K. Vemuri, J.-H. Ho, Y. Wu, L. Wu, P. Popov, O. Benchama, N. Zvonok, K. Locke, L. Qu, G. W. Han, M. R. Iyer, R. Cinar, N. J. Coffey, J. Wang, M. Wu, V. Katritch, S. Zhao, G. Kunos, L. M. Bohn, A. Makriyannis, R. C. Stevens, Z.-J. Liu, Cell 2019, 176, 459. 